\title{
Students' loyalty in higher education: The mediating effect of satisfaction, trust, commitment on student loyalty to Alma Mater
}

\section{Damira Ismanova $a^{a^{*}}$ \\ ${ }^{a}$ Girne American University, Cyprus}

\begin{tabular}{l}
\hline C H R O N I C L E \\
\hline Article history: \\
Received: March 14, 2019 \\
Received in revised format: April \\
192019 \\
Accepted: April 29, 2019 \\
Available online: \\
April 30, 2019 \\
\hline Keywords: \\
Perceived Service Quality \\
Student satisfaction \\
Trust \\
Commitment \\
Student loyalty \\
Structural Equation Modeling \\
PLS
\end{tabular}

\author{
A B S T R A C T
}

\begin{abstract}
Students' loyalty enhances sustainability and survival rate of higher education institutions. Successful university managers and higher education thrive to improve service quality and to build loyalty among local and international students to sustain under the globalization. The aim of this research was to investigate the mediation effect of some key long-term relationship antecedent variables such as trust, satisfaction, and commitment between the perceived service quality and student loyalty latent variables. The relationship between the constructs in the instrument was tested through Partial Least squares (PLS) structural equations methodology using SmartPLS 3 program. The results of this research show that perceived service quality impacts loyalty specifically through commitment. Students' loyalty is significantly influenced by commitment. However, student satisfaction has no significant direct effects on loyalty. Student trust has a negative effect on student loyalty so the results indicate that commitment fully mediates the effects of perceived service quality on student loyalty. Hence, university managers revitalize and sustain students' loyalty if along with high quality services they also stimulate bonds and students identification with the university by reinforcing emotional force such as commitment.
\end{abstract}

\section{Introduction}

Successful university managers and higher education state policies thrive to improve service quality and to build loyalty among local and international students to have sustainable progress. During the last decade, the number of North Cyprus universities has been rapidly increased from 7 to 18 . The number of local and international students dramatically has increased from 43,328 to 101,026 students between 2009 and 2018 (Sin, 2018) where $87 \%$ of them are international and $13 \%$ are domestic students. In this period, the percentage of international students was increased by $22.5 \%$ while the percentage of local students was decreased by $8 \%$ (State Planning Organization, 2018). Education quality, reputation, and location are the key factors influencing a decision to study abroad (Kend et al., 2017). Universities that retain postgraduate students contribute to the country economic welfare, boost lifelong learning and exploit innovative areas of research (Donaldson \& McNicholas, 2004). It is the key success for universities to keep up with the state of art relationship marketing strategies to survive in the highly competitive environment (Curth et al., 2019; Helgesen, 2008). Prominent managers feel the urge to scrutinize and build student loyalty in order to develop fruitful long-term relationships between students and alma mater (Pedro et al., 2017). 
Some studies suggest that loyalty is mainly determined by the dimensions of relationship quality and the determinants of long-term relationship student loyalty model include: perceived service quality, trust, and commitment (Hennig-Thurau et al., 2001). Rojas-Méndez et al. (2009) added the concept of satisfaction into the model and concluded that the commitment is the most substantial factor that impacts directly the student loyalty and other antecedents have only indirect influence on student loyalty. However, other studies testified the satisfaction directly influences loyalty (Alves \& Raposo, 2007; Helgesen Øyvind \& Nesset Erik, 2007). A recent Meta-analytic study reported that there are contradictions of reported results for consequents between satisfaction and intention to recommend in higher education (de Oliveira Santini et al., 2017). The results regarding the direct effect of trust in the formation of loyalty also differ (Hoffmann Sampaio et al., 2012). Although literature represents a vital contribution to the understanding of long-term relationships student loyalty model, there is still some inconsistency of reported results that might be explained by the lack of research of this kind and it is unclear how the relationship between antecedents of student loyalty model can be manifested in the different competitive and geographical contexts. Existing literature fails to offer a complete justification of how the individual dimensions for example such as trust can endure and sustain loyalty. Thus, the aim of this research is to investigate the mediation effect of key long-term relationship antecedent variables such as trust, satisfaction and commitment between the perceived service quality and student loyalty latent variables. The research model is tested by using the Partial Least Squares (PLS) structural equations modeling techniques.

\section{Literature review}

\subsection{Student Loyalty in Higher Education}

According to Royce (1908) "Everybody has heard of loyalty, but few perceive it to be what, in its inmost spirit". The author also explained that "a human is loyal when: he has a cause, he willingly dedicates himself to this cause, he devotes in a sustained manner through acting steadily in respect of this cause". Loyalty is a stable commitment to repurchase product or service from the same brand, despite the presence of different obstacles (Oliver, 1999). For managers to reach loyalty the product must: have appropriate configuration, be considered by the customer as desirable, be subject to adoration to potentially loyal consumers, be implanted in a social network, be invested in and cherished in order to increase demand and sustain social network (Oliver, 1999). According to Hennig-Thurau et al. (2001) perceived service quality and students' commitment are the key factors of student loyalty. Service quality, trust, and emotional commitment are consistently positive, strong, and significant. The path from trust to commitment is positive but non-significant (Hennig-Thurau et al., 2001). Helgesen Øyvind and Nesset Erik (2007) scrutinized the relationships between service quality, facilities, student satisfaction, image, and student loyalty. They reported that satisfaction had a direct effect on loyalty. Rojas-Méndez et al. (2009) reported that trust and student satisfaction had some indirect effects on loyalty. The authors established relationships in a subsequent direct order: perceived service quality, satisfaction, trust, and commitment. Also, Orozco Encinas and Cavazos Arroyo (2017) reported that loyalty of postgraduate students to the alma mater could be explained by commitment and participation in co-creating the service.

\subsection{Perceived Service Quality}

Parasuraman et al. (1988) drew a parallel line where the distinction between service quality and satisfaction is the same as a distinction between attitude and satisfaction. They also explained perceived service quality as "a global judgment, or attitude, relating to the superiority of the service, whereas satisfaction is related to a specific transaction". SERVQUAL is usable in a wide range of services (Parasuraman et al., 1988). The study reduced the number of previously reported dimensions from 10 (Parasuraman et al., 1985) to 5 dimensions (consisting of 22 items) and prioritized them from the most to the least important dimensions in predicting overall quality: reliability, assurance, tangibles, responsiveness, and empathy. Abdullah (2006) offered another HEdPERF scale to measure service quality in higher education that includes five factors: non-academic aspects, academic aspects, reputation, access and program issues. 
Perceived service quality is the discrepancy degree of perceptions and expectations. However, literature also supports the simple performance-based measures of service quality (Churchill \& Surprenant, 1982). The level of perceived service quality has a resilient direct impact on student loyalty (Hennig-Thurau et al., 2001). To increase student loyalty through quality-based strategy Hennig-Thurau et al. (2001) recommended universities to identify important service quality aspects. In the context of higher education, Calvo-Porral et al. (2013) reported that tangibility and empathy had more influence on perceived quality than assurance, reliability or responsiveness.

\subsection{Students' commitment}

The committed party believes in the importance of relationship and does efforts to preserve and ensure its distant future (Morgan \& Hunt, 1994). Oliver (1999) informs that commitment happens when consumer desires and prefers to be committed to the object. It is also an emotional force that stimulates bonds and identification with the university. In a higher education context, most of the studies reported that commitment has a significant and positive effect on student loyalty (Hennig-Thurau et al., 2001; Orozco Encinas \& Cavazos Arroyo, 2017; Rojas-Méndez et al., 2009). Thus, commitment is the most powerful factor on loyalty. Rojas-Méndez et al. (2009) reported that perceived service quality, satisfaction, trust, and commitment all together explained $83 \%$ of student loyalty where trust and satisfaction had indirect effects. Satisfaction has an indirect influence on commitment (Pedro et al., 2017). Most of the research studies indicate that commitment factor plays a crucial role in creating loyalty (Yousaf et al., 2018).

Hypothesis 1: The relationship between Perceived Service Quality and Student Loyalty is mediated by Student commitment.

\subsection{Trust}

Relationship quality has been introduced as a three-dimensional variable that includes the customer's product or service related to quality perception, the customer's trust, and relationship commitment (Hennig-Thurau \& Klee, 1997). The trust is an aspect and a determinant of relationship quality. Trust comprises belief and behavioral features. Partner' trust is incomplete if he/she is unwilling to rely on the companion even if he/she believes the companion is trustworthy. Reliance is a function of control than trust if one is willing to rely on a partner but doubt his/her trustworthiness. Moorman et al. (1992) defined trust as a readiness to rely on a partner in whom one has confidence. Customers are likely to terminate a relationship when it is based on a perceived service quality alone. Thus, by adding high levels of trust and commitment managers provide better stability. We develop trust when we continuously receive expected performance we envisage it to be true in the future (Hennig-Thurau \& Klee, 1997). While it is known that perceived quality has a significant, positive, direct effect on student trust (Kunanusorn \& Puttawong, 2015) it is also known that trust has no direct, significant impact on loyalty (Hennig-Thurau et al., 2001; Hoffmann Sampaio et al., 2012).

Hypothesis 2: The relationship between Perceived Service Quality and Student Loyalty is mediated by Trust.

\subsection{Students' satisfaction}

Universities improve retention by viewing students as customers (Guilbault, 2016). Successful managers must treat students as customers for better recruitment and retention. Churchill and Surprenant (1982) defined customer satisfaction as extend of how much the customer is pleased or displeased after the product is bought and used. Service quality and satisfaction have strong bonds, significantly correlated and influenced by the educational context (de Oliveira Santini et al., 2017). Several studies reported that student satisfaction has positive degree of association with student loyalty (Alves \& Raposo, 2007; Chandra et al., 2018; Chen, 2016; Helgesen Øyvind \& Nesset Erik, 2007; Kunanusorn \& Puttawong, 2015; Shahsavar \& Sudzina, 2017). Service quality has a positive and significant influence on student 
satisfaction and student satisfaction has a positive influence on student loyalty. But, there was no significant influence between service quality and student loyalty (Chandra et al., 2018).

Hypothesis 3: The relationship between Perceived Service Quality and Student Loyalty is mediated by Student Satisfaction.

\section{Conceptual Framework of the Study}

The conceptual framework and relations among latent variables of this research are presented in Fig. 1.

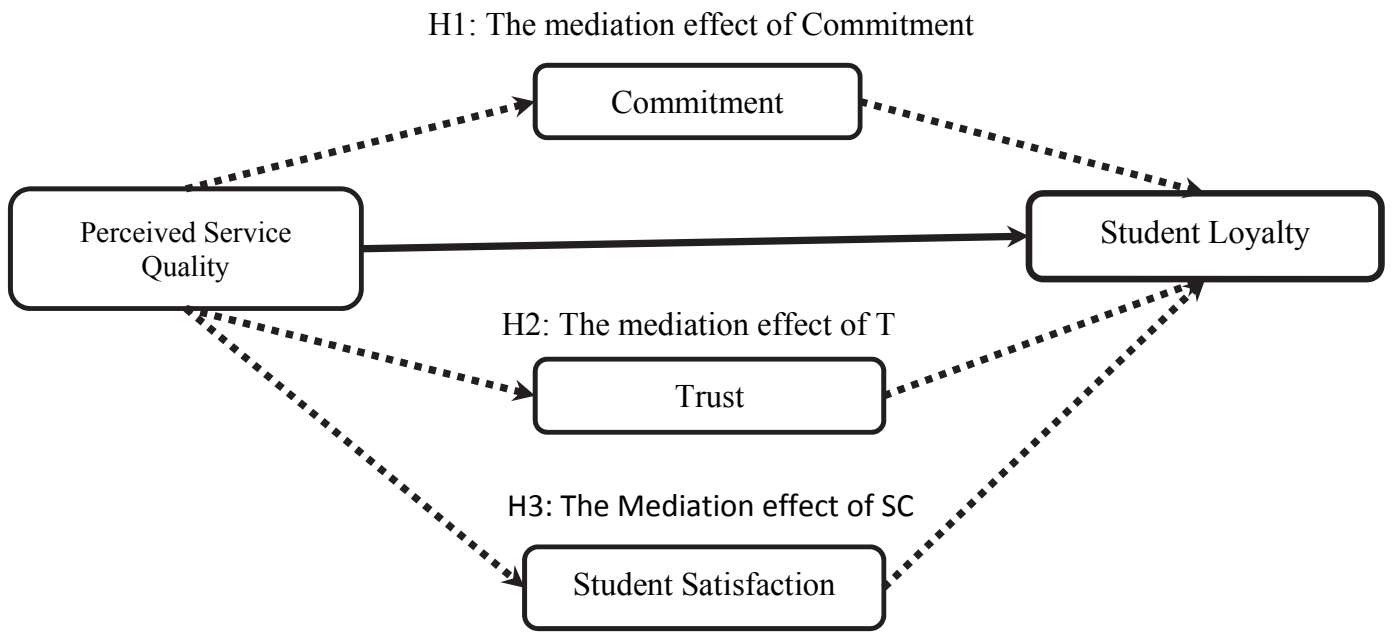

\section{Research methodology}

Fig. 1 Proposed framework

\subsection{Sampling and data collection}

The subjects of this research were undergraduate (218 students) and graduate students (86 students) in private higher education institution in the Northern Cyprus. Students in the research sample were recruited from full-time students in Girne American University. The random sampling technique was used in collecting data. The total sample consists of 304 students; 141 females and 163 males.

\subsection{Measurement}

This research was quantitative and adopted the concept of constructs in the adjusted model from RojasMéndez et al. (2009). The study used five variables: perceived service quality, satisfaction, trust, commitment and student loyalty. The Partial Least Squares (PLS) structure equation modeling (SEM) approach was used to test the model (Nitzl et al., 2016; Emeagwali, 2015; Baron \& Kenny, 1986). PLS is a powerful analytical tool when sample sizes are small and models are complex (Hair Jr et al., 2016). Questions were about students perceived service experiences. The first part of a survey was about demographic details. The second part contained questions on following latent variables: perceived service quality, student satisfaction, student trust, commitment and student loyalty. A seven-point Likert type response format was used, with 1- "Strongly disagree", 2- "Disagree", 3- "Slightly disagree", 4-"Undecided", 5-"Slightly agree", 6-“Agree", 7-“Strongly agree". In measurement model, 16 indicators were used to measure latent constructs: perceived service quality (4 indicators), Student satisfaction (3 indicators), trust (3 indicators), and student loyalty (3 indicators). We test and analyze the data processed by using data analysis PLS technique with SmartPLS3 Program (Ringle, Christian M., Wende, Sven, \& Becker, 2015). There are three criteria in using data analysis techniques with SmartPLS3 to assess the outer model of Convergent Validity, Discriminant Validity, and Composite Reliability (Hair Jr et al., 2016). After evaluating the measurement model hypothesis on mediation effects were tested (Baron \& Kenny, 1986). 


\section{Results}

\subsection{Validating measurement model and validating structural model}

We have used the Partial Least Square (PLS) algorithm to test the structural equation models. This approach maximizes the explanatory and the predictive powers of the model that are evaluated in terms of the $\mathrm{R}^{2}$ values of the dependent variables (between 0.611 and 0.744 ) (Table 1).

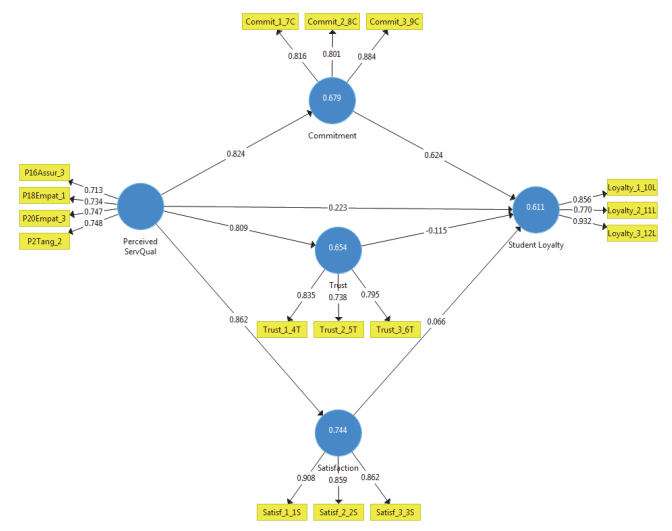

Fig. 1. Estimated Structural Student Loyalty model

Fig. 1 shows the final model with path loading coefficients statistically significant at level 0.05 . The model illustrates the linkages between perceived service quality, commitment, satisfaction, trust, and student loyalty. According to the multiple determination coefficient $\left(\mathrm{R}^{2}\right), 61.1 \%$ of student loyalty variation comes from predictive dimension variations such as perceived service quality, commitment, satisfaction $\left(\mathrm{R}^{2}=.611\right)$.

Table 1

The Measurement model

\begin{tabular}{|c|c|c|c|c|c|c|c|}
\hline Latent constructs & Item & Mean & SD & Standardized loading & Cronbach's a & CR & AVE \\
\hline Perceived & Assur 3 P16 & 0.701 & 0.041 & 0.702 & \multirow{4}{*}{0.825} & \multirow{4}{*}{0.825} & \multirow[t]{4}{*}{0.542} \\
\hline \multirow{3}{*}{ ServQual } & Empat 1 P18 & 0.742 & 0.037 & 0.744 & & & \\
\hline & Empat 3 P2O & 0.756 & 0.035 & 0.759 & & & \\
\hline & Tang $2 P 2$ & 0.737 & 0.036 & 0.738 & & & \\
\hline \multirow{3}{*}{ Student Satisfaction } & Satis $11 \mathrm{~S}$ & 0.902 & 0.024 & 0.903 & \multirow[t]{3}{*}{0.909} & \multirow[t]{3}{*}{0.909} & \multirow{3}{*}{0.768} \\
\hline & Satis $22 S$ & 0.861 & 0.022 & 0.861 & & & \\
\hline & Satis $33 S$ & 0.865 & 0.021 & 0.865 & & & \\
\hline \multirow[t]{3}{*}{ Trust } & Trust $14 \mathrm{~T}$ & 0.834 & 0.032 & 0.835 & \multirow[t]{3}{*}{0.833} & \multirow[t]{3}{*}{0.833} & \multirow[t]{3}{*}{0.624} \\
\hline & Trust $25 \mathrm{~T}$ & 0.737 & 0.035 & 0.738 & & & \\
\hline & Trust $36 \mathrm{~T}$ & 0.796 & 0.038 & 0.795 & & & \\
\hline \multirow[t]{3}{*}{ Commitment } & Commit $17 C$ & 0.819 & 0.030 & 0.818 & \multirow[t]{3}{*}{0.872} & \multirow[t]{3}{*}{0.873} & \multirow[t]{3}{*}{0.696} \\
\hline & Commit $28 \mathrm{C}$ & 0.799 & 0.034 & 0.799 & & & \\
\hline & Commit $39 \mathrm{C}$ & 0.882 & 0.024 & 0.884 & & & \\
\hline \multirow[t]{3}{*}{ Student Loyalty } & Loyalty $110 \mathrm{~L}$ & 0.856 & 0.025 & 0.856 & \multirow[t]{3}{*}{0.891} & \multirow[t]{3}{*}{0.890} & \multirow[t]{3}{*}{0.731} \\
\hline & Loyalty $211 \mathrm{~L}$ & 0.770 & 0.032 & 0.770 & & & \\
\hline & Loyalty $312 L$ & 0.932 & 0.028 & 0.932 & & & \\
\hline
\end{tabular}

Source: Author analysis

Table 1 shows that Cronbach's alpha value of all latent variables are represented between 0.833 and 0.909. Cronbach's Alpha (Malhotra, 1999) was used as a tool, the data gathering instrument with 16 items, reached a 0.909 Cronbach's Alpha coefficient, indicating a high level of reliability. For each reflective latent variable the AVEs squared root exceeds its shared variance with other constructs, thus they are independent from each other. The model-fit indices indicate a good fit to the data.

\subsection{Testing the Hypotheses}

Hypothesis testing can be sorted into direct influence of influence and testing of indirect influence or testing of mediation variables. Based on if the data found that the results of hypothesis testing are presented in Table 2 as follows: 
Table 2

T-Statistics for Path Estimates

\begin{tabular}{llll}
\hline Hypotheses & Standardized estimate & T-Values & Sig. \\
\hline Perceived Service Quality - Student Satisfaction & 0.861 & $23.539^{* *}$ & Significant \\
Perceived Service Quality - Trust & 0.809 & $22.709^{* *}$ & Significant \\
Perceived Service Quality - Commitment & 0.824 & $24.986^{* *}$ & Significant \\
Perceived Service Quality - Student Loyalty & 0.226 & $12.073^{* *}$ & Significant \\
Student Satisfaction- Student Loyalty & 0.066 & 0.376 & Not significant \\
Trust - Student Loyalty & -0.116 & 1.061 & Not significant \\
Commitment - Student Loyalty & 0.623 & $4.454^{* *}$ & Significant \\
\hline
\end{tabular}

Source: Primary Data Processed, 2019

Note: **statistically significant at $5 \%$ level $(\mathrm{t}>1.96)$

Table 2 shows the standardized path coefficients, t-values and test results. The estimates of the structural coefficients provide the base for testing. Perceived service quality has significant, direct and positive effect on student satisfaction. The perceived service quality construct has the largest and positive effect on student satisfaction $(0.861)$.

\subsection{The results mediation test}

\section{Direct, Indirect and Total Effects}

Table 3 shows the direct, indirect, and total effects between perceived service quality, commitment, satisfaction, and trust. The total effect from perceived service quality to student loyalty is 0.740 . This suggests that commitment has the highest degree of association with student loyalty both directly and totally.

Table3

Testing of Indirect Influence Hypotheses

\begin{tabular}{lllllll}
\hline Hyp. & Relationship Between Variables & $\begin{array}{l}\text { Direct } \\
\text { Effect }\end{array}$ & $\begin{array}{l}\text { Indirect } \\
\text { Effect }\end{array}$ & $\begin{array}{l}\text { Total } \\
\text { Effect }\end{array}$ & t-value & Information \\
\hline H1 & Perceived Service Quality - Commitment-Student Loyalty & 0.226 & 0.514 & 0.740 & 4.680 & Significant \\
\hline H2 & Perceived Service Quality - Student Satisfaction - Student Loyalty & 0.226 & 0.057 & 0.283 & 0.598 & Not Significant \\
\hline H3 & Perceived Service Quality - Trust - Student Loyalty & 0.226 & -0.093 & 0.133 & 1.103 & Not Significant \\
\hline
\end{tabular}

Source Primary Data Processed, 2019

\section{Conclusion}

The study found that the commitment fully mediates the relationship between Perceived Service Quality and Student Loyalty. The correlation between perceived service quality and commitment is higher than between commitment and student loyalty. However, both are strong and significant. Perceived service quality did not have so high but positive effect on student loyalty. Perceived Service quality has strong positive and statistically significant correlation with trust. However, the correlation between trust and loyalty is negative and non-significant. Satisfaction has strong direct effect with perceived service quality but very low and non-significant relationship with student loyalty. The study found that there was a mediation effect between perceived service quality and student loyalty specifically it occurs through commitment.

\section{Discussion}

The study found that the major factor influencing student loyalty is commitment. The findings of the study support the results reported by Rojas-Méndez et al. (2009). It was also confirmed that perceived service quality is the antecedent to commitment, trust and student satisfaction and the consequences of student loyalty. Helgesen and Nesset (2007) found that the effect of satisfaction loyalty is direct. However, this study has shown that the effect of satisfaction on student loyalty was low and non-significant. All relationship in this study were positive with the exception of trust which was negatively correlated with student loyalty. This is similar to the results reported by Hoffmann Sampaio et al. (2012) who did not find a positive correlation between trust and loyalty. Such a result reinforces the idea that university staff has no direct, significant influence on student loyalty. The research has provided more understanding on how each factor influences the student loyalty. Positive correlation between commitment and 
student loyalty was strong. Commitment fully mediates the relationship between perceived service quality and student loyalty. These results are consistent with previous research; student loyalty is positively influenced by perceived service quality, satisfaction and commitment. The study has shown that commitment is the most powerful driver on student loyalty. Therefore, university managers develop and sustain students' loyalty if along with service quality they also nourish bonds with students and their identification with the university by strengthening commitment.

\section{Limitation and directions for future studies}

The study has examined the mediating effect of key factors influencing loyalty: commitment, trust and satisfaction in the perceived service quality and student loyalty relationship. Taking into account of the results regarding the negative correlation of trust construct with student loyalty, future research might scrutinize the interrelationships between the latent variables for a profounder exploration. The mediation effect of the variables reflecting long-term relationships can be repeated in order to better understand such a role in the context of higher education in different countries.

\section{References}

Abdullah, F. (2006). Measuring service quality in higher education: Three instruments compared. International Journal of Research and Method in Education, 29(1), 71-89.

Alves, H., \& Raposo, M. (2007). Conceptual model of student satisfaction in higher education. Total Quality Management, 18(5), 571-588.

Baron, R. M., \& Kenny, D. A. (1986). The Moderator-Mediator Variable Distinction in Social Psychological Research: Conceptual, Strategic, and Statistical Considerations. Journal of Personality and Social Psychology, 51(6), 1173-1182.

Calvo-Porral, C., Lévy-Mangin, J. P., \& Novo-Corti, I. (2013). Perceived quality in higher education: An empirical study. Marketing Intelligence and Planning, 31(6), 601-619.

Chandra, T., Martha, N., Chandra, S., \& Priyono, P. (2018). The Effect of Service Quality on Student Satisfaction and Student Loyalty: An Empirical Study. Journal of Social Studies Education Research, 9(3), 109-131.

Chen, Y.-C. (2016). The Impact of Marketing Strategies and Satisfaction on Student Loyalty: A Structural Equation Model Approach. International Education Studies, 9(8), 94.

Churchill, G. A. J., \& Surprenant, C. (1982). An Investigation Into the Determinants of Customer Satisfaction. Journal of Marketing Research, 19(4), 491-504.

Curth, M., Sampaio, C. H., \& Spolavori, R. (2019). Relations in Virtual Education: A study on the antecedents of loyalty. RIED. Revista Iberoamericana de Educación a Distancia, 22(1), 289.

de Oliveira Santini, F., Junior Ladeira, W., Hoffmann Sampaio, C., \& da Silva Costa, G. (2017). Student satisfaction in higher education: a meta-analytic study. Journal of Marketing for Higher Education, 27(1), 1-18.

Donaldson, B., \& McNicholas, C. (2004). Understanding the postgraduate education market for UKbased students: A review and empirical study. International Journal of Nonprofit and Voluntary Sector Marketing, 9(4), 346-360.

Emeagwali, O. L. (2015). WBISS: Web-based Inferential Statistic Selector [Web Application]. Accessed June 6, 2017, from https://lemeagwali.wixsite.com/wbiss

Guilbault, M. (2016). Students as customers in higher education: reframing the debate. Journal of Marketing for Higher Education, 26(2), 132-142.

Hair Jr, J. F., Hult, G. T. M., Ringle, C., \& Sarstedt, M. (2016). A primer on partial least squares structural equation modeling (PLS-SEM). Sage Publications.

Helgesen, Ø. (2008). Marketing for higher education: A relationship marketing approach. Journal of Marketing for Higher Education, 18(1), 50-78.

Helgesen, Ø., \& Nesset, E. (2007). Images, satisfaction and antecedents: Drivers of student loyalty? A case study of a Norwegian university college. Corporate Reputation Review, 10(1), 38-59. 
Hennig-Thurau, T., \& Klee, A. (1997). The Impact of Customer Satisfaction and Relationship Quality on Customer Retention : A Critical Reassessment and Model Development. Psychology \& Marketing, 14(8), 737-764.

Hennig-Thurau, T., Langer, M. F., Hansen, U., Hennig-thurau, T., Langer, M. F., \& Hansen, U. (2001). Modeling and Managing Student Loyalty: An Approach Based on the Concept of Relationship Quality. Journal of Service Research, 3(331).

Hoffmann Sampaio, C., Gattermann Perin, M., Simões, C., \& Kleinowski, H. (2012). Students' trust, value and loyalty: evidence from higher education in Brazil. Journal of Marketing for Higher Education, 22(1), 83-100.

Kend, B., Raif, Y., Yasin, K. M., Dem, C., Hayrettin, A. K., Eylem, C. E. L., ..., \& Den, H. (2017). KKTC Ekonomi Durum Raporu. Retrieved from http://www.kei.gov.tr/media/1814/2017-kktcekonomI-durum-raporu.pdf

Kunanusorn, A., \& Puttawong, D. (2015). The Mediating Effect of Satisfaction on Student Loyalty to Higher Education Institution. European Scientific Journal, ESJ, 11(10), 449-463.

Moorman, C., Zaltman, G., \& Deshpande, R. (1992). Relationships Between Providers and Users of Market Research : The Dynamics of Trust Within and Between Organizations. Journal of Marketing Research, 29, 314-328.

Morgan, R. M., \& Hunt, S. D. (1994). The commitment-trust theory of relationship marketing. The Journal of Marketing, 58, 20-38.

Nitzl, C., Roldan, J. L., \& Cepeda, G. (2016). Mediation analysis in partial least squares path modeling: Helping researchers discuss more sophisticated models. Industrial Management \& Data Systems, $116(9), 1849-1864$.

Oliver, R. L. (1999). Whence Consumer Loyalty ? Journal of Marketing, 63, 33-44.

Orozco Encinas, C. F., \& Cavazos Arroyo, J. (2017). Students' loyalty in Higher Education: the roles of affective commitment, service co-creation and engagement. Journal of Management, 33(57), 96-110.

Parasuraman, A., Zeithaml, V., Berry, L. (1988). SERVQUAL: A Multiple-Item Scale for Measuring Consumer Perceptions of Service Quality. Jorunal of Retailing, 64(September 2014), 12-40.

Parasuraman, A., Zeithaml, V. A., \& Berry, L. L. (1985). Model Service Its Quality and Implications for Future. The Journal of Marketing, 49(4), 41-50.

Pedro, I. M., Pereira, L. N., \& Hélder Brito, C. (2017). Determinants for the commitment relationship maintenance between the alumni and the alma mater. Journal of Marketing for Higher Education, $28(1), 128-152$.

Ringle, Christian M., Wende, Sven, \& Becker, J.-M. (2015). SmartPLS 3. Bönningstedt: SmartPLS. Retrieved from http://www.smartpls.com

Rojas-Méndez, J. I., Vasquez-Parraga, A. Z., Kara, A., \& Cerda-Urrutia, A. (2009). Determinants of student loyalty in higher education: A tested relationship approach in latin America. Latin American Business Review, 10(1), 21-39.

Royce, J. (1908). The Philosophy of Loyalty. The Macmillan.

Shahsavar, T., \& Sudzina, F. (2017). Student satisfaction and loyalty in Denmark: Application of EPSI methodology. PLoS ONE, 12(12), 1-18.

Sin, T. (2018). KKTC Ekonomik Göstergeler Raporu.

State Planning Organization. (2018). Statistical Yearbook 2017 (42nd ed.).

Yousaf, A., Mishra, A., \& Bashir, M. (2018). Brand trust, institutional commitment, and their impact on student loyalty: evidence for higher education in India. Studies in Higher Education, 1-14.

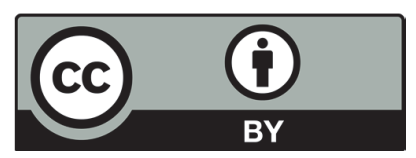

(C) 2019 by the authors; licensee Growing Science, Canada. This is an open access article distributed under the terms and conditions of the Creative Commons Attribution (CCBY) license (http://creativecommons.org/licenses/by/4.0/). 